\title{
INVESTIGATING THE ROLE OF MICRO FINANCE ON ECONOMIC AND SOCIAL DEVELOPMENT OF PEOPLE: A CASE STUDY OF RURAL AREAS OF SIND, PAKISTAN
}

\author{
Muhammad Tariq1 \\ Abdur Rehman Aleemi2 \\ Dr. Athar Iqbal 4 \\ Iqra University, Main Campus Karachi
}

\begin{abstract}
Purpose: This study is designed to investigate the role of micro finance on the economic and social development of people in the rural areas of the Province of Sind Pakistan. This study considers and compares two situations of the respondents: economic and social conditions before and after taking micro loan. Methodology/Sampling: The target population for this study is those people who planned to take micro credit from the banks with objective to change their lives by investing such funds in their existing business or opening new business. We conducted survey about their economic well being before taking micro credit (Feb-July 2013) and than revisited to them after a year and determined their status after taking micro credit. The study considers descriptive as well as statistical analysis such as Chi square, OLS estimation and one sample T test. Findings: The study concludes that there is no change in Economic Conditions of Borrowers after accusation of Micro finance. The micro finance could not improve their Business growth as well. However, in Social Development, there is significant improvement in the Life Style of borrowers, whereas, there is no significant improvement in Health and Education needs of Buyers before and after taking of micro finance. The study further concludes that borrowers believe that the Loan Amount provided is not sufficient for their needs and both the repayment schedule and interest rate are not reasonable to facilitate them. Practical Implications: this study provides bases for new dimensions especially for the policy makers and the regulatory bodies that term structure of Micro credit should be revised as well as the amount of loan should also be sufficient enough for the borrowers' need.
\end{abstract}

Keywords : Financial Distress cost, Liquid assets, investment, employment and sale.

Jel Classification: D920, E220, F210

\footnotetext{
* The material presented by the author does not necessarily portray the viewpoint of the editors and the management of the Institute of Business \& Technology (IBT)

1. Muhammad Tariq

:muhammadtariq1985@gmail.com

2. Abdur Rehman Aleemi

:abdurrahmanjan@gmail.com

3. Dr. Athar Iqbal

:athar@iqra.edu.pk

(C) IBTJBS is published by the Institute of Business and Technology (IBT).

Main Ibrahim Hydri Road, Korangi Creek, Karachi-75190, Pakistan.
} 


\section{INTRODUCTION}

Microfinance or microcredit is attributed by Otero (1999) to be "the provision of financial services to low income poor and very poor self-employed people". Generally Microfinance can be characterized as supplying loans, savings and other related financial services like insurance to the poor segments of the society; who in general have less access to credit and other financial facilities under conventional banking setup. Government of Pakistan (2006) extends the necessity of these services further for the poor or lower segments of the society needed to run their businesses, build assets, stabilize their consumption of basic necessities and to shield themselves against risks of inability to meet the basic subsistence level of life.

Regarding the effectiveness or the role of microfinance in uplifting the peoples' lives, have been quite extensively studied and numerous studies have even documented empirical evidence in this regard as well. And generally it is believed to be one of the imperative initiatives to uplift the livings of peoples, reduce poverty and deprivation and to include the financially excluded segments of the society with a particular emphasis to cater with their particular needs and circumstances. One of the earliest and one of the most cited empirical evidence in this context came from Khandker (1998), while studying the three major and pioneering institutions of Microfinance including the Grameen Bank, BRAC and RD-12 in Bangladesh, concluded that up to 5\% of the participants were able to lift the economic conditions of their families every year by acquiring the facility of microfinance from these institutions. Similarly Littlefield et al. (2003) and Goldberg (2005) summarized the available literature at the timeand found that microfinance participants reported higher incomes than non-participants. They further reported that most of the earlier studies likewise found positive impact of microfinance on poverty and income.

However the matter is still of considerable debate as there are numerous opposite sentiments as well, for example Pitt and Khandker (1998), reworked on their original data and dawned on a new conclusion that 'Strikingly, 30 years into the microfinance movement we have little solid evidence that (microfinance) improves the lives of clients in measurable ways'.

In Pakistan the concept is relatively younger, however like all Microfinance Institutions (MFIs'), are mandated to serve the poor (Setboonsarng et al. 2008), Pakistan is also catering for the same purpose since 2001 with a clear policy to address poverty and the financial needs of the poor. However very less work exists in this regard to measure the impact of these initiatives or the services provided by these MFIs-particularly on the socio economic wellbeing of the target population. Hence this study is particularly designed to investigate the effects of MFIs' services on the improvement of the lives of people in the case of Pakistan with a particular emphasis on the role of micro finance on the economic and social development of people in the rural areas of the Province of Sind Pakistan, targeting those segments of the population who have acquired these services to change their living standard. 


\section{LITERATURE REVIEW}

The extended form of small collateral free institutional loans is known as micro credit is the innovation of Grameen Bank of Bangladesh the pioneered of credit supply to the poor. The quantitative measurement of the scheme of microcredit attracted a great deal of global attention in forefront of researcher, policy makers and households due to its successful, unbiased and enterprise of sustainable development. The microcredit takes a new paradigm in poverty alleviation, economic development and in empowering the poor. The notion of microcredit is comparatively new to Pakistan. However, it is beneficial to be late in Pakistan that the experience of other countries could also be entertained in making decision whether one should go for micro loan or not. Besides positive aspect, black spots of this program also exist that are reviewed in the following selection of recent literature.

Mazumder and Wencong (2013) explored the connection between microcredit and socio economic status of rural poor community of Bangladesh. For econometric analysis they collected primary data based on face to face interview in two phases (April 2009- April 2010) before involvement with microcredit program and after involvement with program from the same sample of 360 microcredit borrowers. They also considered a control group of non credit borrower respondents to assess the effectiveness of program. Multiple regression method along with Chi square and $\mathrm{F}$ test were performed to analyze the role of micro credit program in cutback the poverty by considering the change in income, assets, living standard and poverty. The results revealed that the number of poor which were 86.7 percent before involvement with microcredit program reduced to 40 percent after involvement with the program. This implied a significantly positive connection between microcredit and poverty diminution. While the level of poverty remained unaffected for control group.

Rahman and Khan (2012) investigated the efficacy of microcredit program by focusing on the correlation between the socioeconomic characteristics of borrowers and program's usefulness for the Bangladesh. The special focus of the paper was to assess the microcredit functioning of ASA program. For quantitative analysis bivariate and multivariate analyses were used. Cross tabulations method was conducted for bivariate analysis and for relationship between dependent and independent variables chi square test was performed. At the end by incorporating all the independent variables Logit model was built up on primary data. The results revealed out immense mainstream of ASA microcredit borrowers who showed positive attitude toward it. The study confirmed the effectiveness of ASA program on the basis of existing literature and its own finding and revealed that beneficiaries of ASA experienced improvement in their socioeconomic status including income, education, living standard, technical and business skills and social awareness. The longer the duration of involvement with this programme the better the results.

Durrani et al. (2011) scrutinized the economic and social aspects of micro finance in poverty reduction. The social and economic factors constituted of upgrading of accommodation, business and life style, income accumulation, purchasing power and 
implementation of improved technology. The study also considered economic expansion and development. The study revealed that the poor could improved their consumption and risk management, progressively accumulate their assets, build up their micro enterprise and could enjoy better life style only with access and proficient stipulation of microcredit. It was argued that microfinance institutions could better perform in poverty reduction than usual with little effort.

Abiola and Salami (2011) highlighted the negative aspects of microfinance along with its positive characteristics. They argued that microfinance would not profitable all the time but it could bring negative outcomes of the program. The reason they explored for the negative impact of microfinance was the time shortage. For the generation of future income time was not enough for loan to work out. The study mentioned that the business of loan taker would collapse at the time of repayment as he was not in the repayment position. The study further explained that time shortage would put an additional pressure on the borrower as his business was in the middle of progression at the time of repayment so all his money and time would lost and the program would be inefficient at all.

Ali and Alam (2010) explored the importance of microfinance for the rural areas of Pakistan. They mentioned that microfinance could affect social and economic life of people positively through poverty elimination and provision of better standard of living. In Pakistan the requirement of microcredit in rural areas is greater than urban areas as most of the population is living below the standard poverty line. They highlighted the positive as well as negative aspects of microfinance program confronted to the Pakistani nation. The study revealed that high rate of interest on microcredit was the most common problem faced by the borrowers but inspite of that the demand for credit remained high because people had not access to commercial loans. They further mentioned that the Pakistanis are hard working and might be blessed with innovative business techniques so they would be ready to borrow micro loans on high interest rates.

Okpara (2010) directed his research to investigate those crucial factors that led to poverty in Nigeria and further explained the role of microfinance institutions in the mitigation of poverty. To explain the variations in two variables that were mainly the role of micro credit and poverty reduction, regression analysis based on quadratic equation model was performed in this study. The results of the study brought about five fundamental reasons of poverty in Nigeria including low rate of profit, high commodity prices and finance deficiency to start new or exaggerate business. The results further indicated the positive and significant impact of micro credit on poverty diminution in Nigeria.

Ruben and Canlas (2009) presented the indicators of poverty and discussed the reasons of inequality and hindrance to the economic growth of Bangladesh. They discussed how microfinance brought gender equality and setup social capital by mitigation of poverty. They presented a broad conceptual framework covering different models of poverty which highlighted the importance of social capital in poverty alleviation. They particularly mentioned the role of Grameen bank as microfinance institution still working in Bangladesh since 1976. Grameen worked differently by having over seven 
millionsmembers it brought 48 percent of its members up from extreme poverty line. Poverty in Bangladesh led to the social exclusion of poor and gender inequality but Grameen provided broad services which other formal banks failed to do so as 97 percent of members were women which was sign of gender equality in Bangladesh. Tenaw and Islam (2009) revealed the importance of microfinance and its impact on the rural community of Bangladesh and Ethiopia. They highlighted the drawbacks of local financial system and emphasized the role of microfinance to overcome all the hurdles confronted to these economies. The study mentioned agriculture the major income sector in Bangladesh and Ethiopia with all its poor aspects of dependency on unexpected weather, fragile market structure and poor technology and infrastructure. They further mentioned that to eliminate poverty the stable agriculture sector was needed which could only possible through accumulation and proper use of microfinance. Knight and Farhad (2008) declared the direct impact of micro finance on poverty diminution and living standard of households. Consumers could built their own enterprises and defend themselves for the outer threats by receiving loans. Being employed they could raised themselves from extreme poverty line and led to overall poverty reduction. The study emphasized to highlight the positive aspects of microfinance so that more and more benefits could be acquired.

Siddiqi (2008) discussed the conventional and Islamic aspects of microfinance in Pakistan. The author mentioned that the performance of microcredit in Pakistan was bewildered that whether it had positive role or negative. He further mentioned the hurdles confronted to the program of microfinance in Pakistan. The first and foremost hurdle was high rate of interest charged by MFIs and the second obstacle was interest or Riba itself. In Pakistan having Islamic society Riba is not allowed hence micro loans are not encouraging. The third hurdle was women's empowerment because they ill treated for receiving loans by the male relatives. The study concluded that Islamic micro credit was superior to conventional micro loans because it was not only profit generation but also full fill the requirements of the poor.

Zeller and Sharma (2000) conducted a multi country research study to analyze the association between credit access, food security of households, insurance and saving program. The study carried out a comprehensive conceptual framework to address various policy questions about the role and functioning of micro finance and presented a combination of empirical results for ten Asian and African countries. The study concluded that poor's capability to endure with risk and outreach of MFI to the poor could be enhanced by putting up credit, saving and insurance program. Due to the complex nature of insurance services precautionary saving could be best substitute for the poorest.

Wright (1999) distinguished the two terms rising income and reducing poverty by exploring the income effect of microcredit. As the two terms always taken alike but he argued that the two are not identical. He supported his view by arguing that the use of income distinguished the two terms, if increased income spent on unproductive means like cinema, on alcohol and at tea stall then there is no improvement or expansion in wealth and no poverty reduction. So, the use of income is as much important in poverty determination as income level itself. The study also emphasized on the quality difference 
of employment in formal and informal sector. The study concluded that poverty could be reduced through sound services of microfinance under appropriate economic conditions.

Mosley and Hulme (1998) directed their study to seven countries and investigated the relationship between growth and poverty alleviation in the context of microenterprise financing by analyzing the impact of microfinance institutions on poverty and other selected variables. The study confirmed significant impact of microfinance on poverty at one percent level of significance as income and asset level of households improved as the lending level increased. They found on the basis of impact curve which slope vary with the institution's design that the impact of well planned schemes were greater than poor planned schemes on all income levels. They concluded that trade-off of lending bodies could only be stimulated by improving the institutional services like collection of loans, motivational plans for borrowers and amendments to savings.

\section{RESEARCH METHODOLOGY}

\subsection{Sample Size and Sampling Technique}

A sample of 153 respondents has been surveyed from six cities of Province Sind. The Convenient sampling method has been made for data collection. We approach both male and female participants from rural areas.

\subsection{Instrument for Data Collection}

The data collection methodology includes a field survey in rural areas where Micro Finance was availed by the people. Hence the population for this study is Micro Finance Borrowers. The data collection has been made in two phases: in first phase (which started Feb-July 2013) date was collected from those who applied or intended to apply for Micro Finance from the Micro Banks within selected six districts. A total of 153 respondents were interviewed in first phase. In the second phase the same respondents after almost one year (June-July, 2014) were contacted to observe the difference if any in their social well being.

A questionnaire has been prepared on Likert scale with five options coded from 1 till 5. 1 is coded for Strongly Disagree and 2 for Disagree, 3 for Neutral, 4 for Agree and 5 for Strongly Agree.

\subsection{Conceptual Framework}

For our study the following is the conceptual framework. This study investigates whether microfinance has significant contribution in improving the social well being of the people in Pakistan. The conceptual Framework is designed in figure 1 The term social well being here represents both the social as well as economic conditions. If the economic conditions improve, it is also likely that social conditions such as life style, Health and Education will also get improved. The Micro Banks in Pakistan offers micro credit with two classifications: Agri-based and Business Based. The Agri based finance is offered to Invest in the Agricultural Farms, whereas, Business based finance is offered to be invested in either starting a new business or expanding existing business. 


\subsection{Research Model}

The study was initially carried out comparing the effect of microfinance on the well being of people before and after taking the micro loan by considering the factors such as: income, business, life style, health and education needs. To measure the change and the association we applied the Chi Square and F-stats. However, we applied the multiple regressions to test factors related to income, business, life style, health and education needs.

\section{Model}

$$
Y=\beta_{0}+\beta_{1} X_{1}+\beta_{2} X_{2}+\beta_{3} X_{3}+\beta_{4} X_{4}+\varepsilon
$$

For the purpose of this study we consider following predictors for change in the Income Level:
LA Loan Amount Received
Ex Expense
EM No of Earning Members
FM No of Family Members
Y represents the Income Level of the Respondents

\section{Income Level}

The responds earns Income via one or more means including, agriculture such as: self cultivation or cultivation being a farmer, or being, self business or employment. The income level has been classified into three basic categories on monthly level which are as follows:

$$
\begin{gathered}
\text { Income Level A: Up to } 8000 \text { per month } \\
\text { 8001-15000 per month } \\
\text { More than } 15000 \text { per month }
\end{gathered}
$$

\section{RESULTS OF THE STUDY}

This study is based on primary source of information whereby a sample of 430 borrowers of Micro loan has been interviewed.

\subsection{Descriptive Results of the Survey}

This sample is comprised of rural and urban areas of 6 cities of Sind Province; the sample is summarized in Table 1. The Target for sample was at least 90 to 100 respondents from each city; however, we could effectively conducted interview from the sample from each city as provided in Table 1 (see appendix).

The Gender Distribution of our sample was such as: male $62 \%$ and female $38 \%$. We tried our best to make sample of 50\% each gender, but we could not meet many women in this regards. Table 2 (see appendix) sows the Gender Distribution of the sample. The Micro finance Banks in Pakistan offer various products to the expected Borrowers for instance Micro Finance to initiate new Business or expanding existing Business or to invest in Agricultural Crops etc. To make the analysis more clear the Micro Finance has been classified into two main Categories viz-a-viz Agri Based Finance and Business 
Based Finance. Table 3 (see appendix) shows the categories of micro finance and number respondents who have acquired such finance. In sample of $430,55 \%$ availed Business Based finance and out which majority (68\%) acquired finance to start new business whereas $45 \%$ of total sample acquired agri-based finance. Majority of them $(65 \%)$ obtained finance for expansion in their dairy or cattle related objectives. It is important to notice the amount of micro finance availed. Table 4 (see appendix) describes various ranges of Finance and number of responded acquired the Finance within those particular ranges. Most of the borrowers (39\%) fell in category Rs2500150000 and $24 \%$ of total sample acquired finance of Rs10000-250000. It is worth to note that $83 \%$ of total sample individually acquired finance in range of Rs. 10000 to 100000. During the interviews, most of the respondents justified that they needed higher amount but due to hard requirement and heavy interest amount they could not acquired higher amount of finance. 5\% could acquire Finance in the range of Rs 150001 to 300000 and only $1 \%$ could manage to avail Rs 300001-500000.

This study applies statistical test on the primary data collected. Since the survey questionnaire was based on likert scale hence the one sample T-test has been applied to test hypotheses. The results of the one sample Test are summarized in Table 5 (see appendix). The test value has been taken as 4 , because value 3 is a code for Neutral and 4 is a code for Agree. It means statement in questionnaire can be considered as agreed or accepted if sig value is more than 0.05 . The next condition shall be that if average response is more than 4 , i.e. it is strongly agreed by most of the respondents. It means if mean difference is positive we shall accept the hypothesis.

\section{Reliability Test of the Data}

The reliability Test of the data has been test by applying the Cronbach's Alpha statistics. The results are shown in Table 5 (see appendix). The Cronbach's Alpha value is 0.678, which is sufficient for the reliability.

\subsection{Association between Income Level and Micro Credit}

H1: There is change in Income Level before and after taking Micro Credit In order to determine change if any in income level before and after taking Micro Loan, the Chi Square test has been applied. The results of Chi Square test are shown in tables table 6A to $\mathrm{C}$ and Table 7 (see appendix). The contingency tables for three levels of Income has been shown in tables $6 \mathrm{~A}$ to $\mathrm{C}$. Table $6 \mathrm{~A}$ shows that there were 51 respondents with salary level up to 8000 monthly, after taking Micro Loan it reduced to 48 showing that only 3 respondents have switched to higher level of income. However, there is increase in respondents in 8001 to 15000 , showing that after taking micro loan other than three candidates from lower level are switched to this level but also some candidates have switched from higher level to this level.

Table 7 shows the summarized results of Chi-Square. The results accept the Null Hypothesis that there is no dependency of Income before and after taking Micro Credit because the sig value for all three levels is insignificant.

\subsection{OLS Estimation for Change in Income Level}

The results of Chi-Square evidence that there is no dependency relation between income level and microcredit. The OLS estimation has been applied to determine the factors 
causing change in income level. The OLS model for the study is given as follows:

$$
Y=\beta_{0}+\beta_{1} L A+\beta_{2} E x+\beta_{3} E M+\beta_{4} F M+\varepsilon
$$

Y Average Income Level

LA Loan Amount Received

Ex Expense

EM No of Earning Members

FM No of Family Members

The results the OLS estimation is summarized in table 8 (see appendix). The results suggest that change in the Income Level of respondents during the interval of before and after taking the micro credit is due to monthly expense level and number of Earning Family members as their sig value is significant. Both of them create positive effect on Income Level. There is insignificant effect of Micro Loan Amount and number of Family Members on the Income Level.

\section{Social and Economic Effects of Micro Loan}

The Survey has been statistically analyzed by applying the One Sample T-Test. The results of the Test are summarized in Table 8 (see appendix). The analysis has been interpreted as follows:

\section{Proposition 1: Micro Finance has Improved Economic Conditions of Borrowers} The mean difference for first hypothesis is negative and the sig value is also less than 0.05 hence the claim in first question cannot be accepted that Monthly Income has increased after taking Micro Loan. Likewise the claims in second, third and the fourth questions also have negative mean difference and sig value lesser than 0.05 , hence we cannot accept these hypotheses. It means respondents reject the claim that Monthly Income has increased after taking Micro Loan. The respondents also reject that Business has improved after taking Micro Loan and that Business can be expanded by taking Micro Loan.

All the three statements related to Economic conditions are rejected that it means the respondents did not consider Micro Finance as a source to improve their Economic Conditions.

Proposition 2: Micro Finance has improved Social Conditions of borrowers The social condition has been defined by three important aspects: Life style, Health and Education.

\section{Life Style}

The respondents accept the claim in fifth question that their clothing has improved after taking Micro Loan since the mean difference for fourth question is positive. Likewise, the claim in sixth, seventh and eighth questions is also accepted. It means the respondents agree that their Footwear such as shoes etc. needs has improved after taking Micro Loan and their Travelling Style such as travelling via local buses or via own cycle or scooter etc has improved after taking Micro Loan.

\section{Health}


In comparison for effect before and after taking of micro loan on Health need, it has been agreed that Borrowers can Easily Approach to better Medical Centre after taking Micro Loan. However, the respondents did not agree that any significant effect has taken place on their nutrition needs or purchase of expensive medicines after taking of micro Finance.

It suggests that there is no significant improvement in Health needs of Buyers before and after taking of micro finance.

\section{Education}

The claims in 13th, 14th, 15th and 16th questions were designed to determine any improvement made in Education Needs after acquisition of micro finance. The mean difference for 13th question is positive hence the claim can be accepted that respondents can easily afford better schooling after taking Micro Loan. However, the mean difference of 14th , 15th and 16th questions is negative it means that it is difficult for respondents to afford schooling needs of children after taking Micro Loan and likewise it is difficult for respondents to afford higher education after taking Micro Loan.

\section{Response of Borrowers about Micro Finance Terms}

The analysis also took into consideration the underneath feelings of satisfaction or dissatisfaction with Amount, and Terms and conditions being offered by the Micro finance Banks. The claims 13 to 15 were designed to test the response of the Borrowers about the terms of borrowers. The mean difference of 13,14 and 15 hypotheses is negative; it means the respondents disagree with all these claims. According to these Borrowers the Loan Amount provided is not sufficient for their Needs, as we already observed in table 4 that $39 \%$ of selected sample fell in category Rs25001-50000, whereas $83 \%$ of total sample individually acquired finance in range of Rs. 10000 to 100000 . Moreover the respondents were also not satisfied with repayment schedule. The interest rate range in most of the Micro finance Banks is 22-33\% for various products, the respondents believe that Rate of Interest charged is not Reasonable

\section{CONCLUSION AND RECOMMENDATIONS}

This study concludes that there is no change in Economic Conditions of Borrowers after accusation of Micro finance. The micro finance could not improve their Business growth as well. However, in Social Development, there is significant improvement in the Life Style of borrowers such as improvement in clothing, footwear and traveling mode has agreed. In regard of health need this study concludes that there is no significant improvement in Health needs of Buyers before and after taking of micro finance, however, the borrowers agree that they can afford initial fees of doctor so they can reach the medical centers. The similar feelings have been observed for education needs. The respondents agree that there is no significant improvement in Education needs of Buyers before and after taking of micro finance, however, the borrowers agree that they can afford initial Schooling fees so they can get admission of their children in better school but it is very difficult for them to afford the other educational expenses. The study concludes that borrowers believe that the Loan Amount provided is not 
sufficient for their needs, since the descriptive results of the study suggest that $83 \%$ of total sample individually acquired finance in range of Rs. 10000 to 100000 . Interestingly, only 39\% of selected sample fell in category Rs25001-50000. The interest rate range in most of the Micro finance Banks is $22-33 \%$ for various products, the respondents believe that Rate of Interest charged is not Reasonable.

\section{RECOMMENDATION}

1. Amount of Micro Credit must be Sufficient

2. The rate of Interest on Micro Credit must be lower than or at most equal to Commercial Lending rate

3. The Micro Loan must be given to adequately qualified person with business and technical skills

\section{ACKNOWLEDGEMENT}

First of all with a profound gratitude, we are thankful to Almighty Allah forgiving us success, knowledge and understanding without which we would not been capable of completing this research paper.

We are also profoundly grateful to all our family members whose endurance and understanding have played a significant role in our success by sacrificing the important family time and supporting us all over the research work.

We are finally thankful to the editor, reviewers and IBT specially who provided us with the opportunity to publish our research paper in this esteemed journal.

\section{REFERENCES}

Abiola, I., \& Salami, A.O. (2011). Impacts of Micro-finance Bank on Standard of Living of Hairdresser in Ogbomoso North Local Government of Oyo State, Nigeria. International Business Management, 5(1): 27-32.

Aideyan, O. (2009). Microfinance and poverty reduction in rural Nigeria.Savings and Development, 293-317.

Aideyan, O. (2009). Microfinance and poverty reduction in rural Nigeria. Savings and Development, 293-317.

Bushell, B. (2008). Women entrepreneurs in Nepal: what prevents them from leading the sector?. Gender \& Development, 16(3), 549-564.

D'Espallier, B., Guérin, I., \& Mersland, R. (2009). Women and Repayment in Microfinance'. Status: published.

Durrani, M. K. K., Usman, A., Malik, M. I., \& Ahmad, S. (2011). Role of micro finance in reducing poverty: A look at social and economic factors. International Journal of Business and Social Science, 2(21), 138-144.

Hulme, D. (2000). Impact assessment methodologies for microfinance: theory, experience and better practice. World development, 28(1), 79-98.

Hulme, D. Impact Assessment Methodologies For Microfinance: Theory, Experience And Better Practice. 
Government of Pakistan (2006). Poverty and Social Impact Assessment: Pakistan Microfinance Policy. Oxford Policy Management.

Khandker, S. (1998). Fighting Poverty with Microcredit: Experience in Bangladesh.New York: Oxford University Press.

Knight, T., \& Farhad, H. (2008). Helping the Needy, Factors Influencing the Development of Microfinance in Barbados. Brooks World Poverty Institute, 1-17.

Littlefield, E., J. Morduch and S. Hashemi (2003). Is Microfinance an effective strategy to reach the Millennium Development Goals?CGAP Focus Note No 24, January.

Mayoux, L. (2000). Micro-finance and the Empowerment of Women: A Review of the Key Issues. Geneva: ILO.

Mazumder, M. S. U., \& Wencong, L. (2013). Micro-credit and poverty reduction: A case of Bangladesh. Prague Economic Papers, 22(3), 403-417.

Mosley, P., \& Hulme, D. (1998). Microenterprise finance: is there a conflict between growth and poverty alleviation?. World development, 26(5), 783-790.

Okpara, G. C. (2010). Microfinance banks and poverty alleviation in Nigeria.Journal of Sustainable Development in Africa, 12(6), 177-191.

Pitt, M. and S. Khandker (1998) 'The impact of group-based credit programs on poor households in Bangladesh: does the gender of participants matter?', Journal of Political Economy106(5): 958-96.

Plogmann, S., Adeel, M., Nett, B., \& Wulf, V. (2010). The Role of Social Capital and Cooperation Infrastructures within Microfinance-Rethinking the example of the Grameen Bank. Proc. of COOP'10, 223-244.

Ruben D. Canlas Jr. (2009). Thinking Micro. Poverty Alleviation through Microfinance, Social Capital and Gender Equality in Bangladesh. Economics of Development, Carnegie Mellon University.

Shastri, R. K. (2009). Micro finance and poverty reduction in India (A comparative study with Asian Countries). African Journal of Business Management, 3(4), 136-140.

Shirazi, N. S., \& KHAN, A. U. (2009). Role of Pakistan Poverty Alleviation fund's Micro Credit In Poverty Alleviation: A Case of Pakistan. Pakistan Economic and Social Review, 215-228.

Siddiqi, K., (2008). Potential of Islamic Microfinance in Pakistan. Discussion paper series, $1-95$

Tenaw, S., \& Islam, K.M.Z., (2009). Rural Financial Services and Effects of Microfinance on Agricultural Productivity and on Poverty. University of Helsinki Department of Economics and Management (Discussion Papers series), 1-28.

Weiss, J., Montgomery, H., \& Kurmanalieva, E. (2003). Micro finance and poverty reduction in Asia: what is the evidence?

Wright, G. A. (1999). Examining the impact of microfinance services-increasing income or reducing poverty?. Small Enterprise Development, 10(1), 38-47.

Zeller, M., \& Sharma, M. (1998). Rural finance and poverty alleviation (No. 8). International Food Policy Research Institute (IFPRI).

Zeller, M., \& Sharma, M. (2000). Many borrow, more save, and all insure: implications for food and micro-finance policy. Food policy, 25(2), 143-167. 


\section{APPENDIX}

\section{Figure 1 Conceptual Framework}

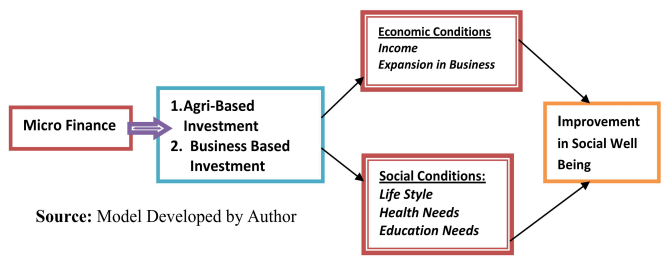

Figure-2: Pakistan's Microfinance Sector highlights. Source: Pakistan Microfinance Review 2013.

\begin{tabular}{|c|c|c|c|c|c|}
\hline YEAR & 2009 & 2010 & 2011 & 2012 & 2013 \\
\hline Active Borrovvers (in millions) & 3.4 & 1.6 & 1.7 & 2. 0 & 24 \\
\hline \multicolumn{6}{|l|}{ Gross Loan Portfolio } \\
\hline (PKR billions) & 16.8 & PKR 20.2 & PKR 24.8 & PKR 33.1 & PKR 46.6 \\
\hline \multicolumn{6}{|l|}{ Active Wamen Barrowers } \\
\hline (in millions) & 0.6 & 0.8 & 0.9 & 1.3 & 1.4 \\
\hline Branches & 1.221 & 1.405 & 1.550 & 1.460 & 1.605 \\
\hline Total Staff & 11.557 & 12,005 & 14202 & 14,648 & 17.456 \\
\hline \multicolumn{6}{|l|}{ Total Assots } \\
\hline (PKR billions) & 30.4 & 35.8 & 48.6 & 61.9 & 215 \\
\hline \multicolumn{6}{|l|}{ Deposits } \\
\hline (PKR billions) & 7.2 & 10.1 & 13.9 & 20.8 & 32.9 \\
\hline \multicolumn{6}{|l|}{ Total Debt } \\
\hline (PKR billions) & 23.2 & 27.5 & 38.3 & 24.9 & 269 \\
\hline \multicolumn{6}{|l|}{ Total Reverive } \\
\hline (PKR billions) & 6.4 & 7.5 & 10.1 & 12.5 & 173 \\
\hline oss (porcerrago) & 104.6 & 99.7 & 108.4 & 109.5 & 118.1 \\
\hline FSS (percentage) & e6.8 & 81.7 & 100.5 & 107.5 & 1165 \\
\hline PAR > 30 (percentage) & 3.4 & 4.1 & 3.2 & 3.7 & 25 \\
\hline
\end{tabular}

Figure-3: Pakistan's Microfinance Sector outreach. Source: MicroWATCH, issue 32. OUTREACH (ALL PAKISTAN) (A nril- Iıne 2014)

\begin{tabular}{|c|c|c|c|c|c|c|c|c|c|c|}
\hline \multirow[t]{2}{*}{ Province } & \multicolumn{2}{|c|}{ Offices } & \multicolumn{2}{|c|}{ Miar ocredit } & \multicolumn{2}{|c|}{ Micro-Savings } & \multicolumn{2}{|c|}{ Micro-Insurance } & \multirow{2}{*}{$\begin{array}{l}\text { Potential } \\
\text { Micofinance } \\
\text { Market }\end{array}$} & \multirow{2}{*}{$\begin{array}{l}\text { Penetration } \\
\text { Rate (N) }\end{array}$} \\
\hline & Fived I & Mobile & $\begin{array}{c}\text { Active } \\
\text { Borrowers }\end{array}$ & $\begin{array}{l}\text { Gross Loan } \\
\text { Portfolio (PYP) }\end{array}$ & $\begin{array}{l}\text { Adtive } \\
\text { Savers }\end{array}$ & $\begin{array}{c}\text { Value of } \\
\text { Savings (PKR) }\end{array}$ & $\begin{array}{l}\text { Policy } \\
\text { Holders }\end{array}$ & $\begin{array}{l}\text { Sum Insur ed } \\
\text { (PFR) }\end{array}$ & & \\
\hline Balochistan & 14 & - & 21,397 & $246,932,157$ & 111,901 & $369,366,114$ & 4,962 & $86,072,626$ & $1,656,762$ & 1.3 \\
\hline KP & 86 & 4 & 94,068 & $1,507,141,681$ & 283,512 & $2,014,806,588$ & 76,155 & $1,157,298,799$ & $4,083,817$ & 23 \\
\hline Punizos & 1,548 & 8 & $2,246,105$ & $44,167,430,715$ & $3,169,210$ & $16,120,126,445$ & $2,433,845$ & $35,598,558,910$ & $15,233,924$ & 14.7 \\
\hline Sinch & 625 & - & 709,291 & $13,957,335,676$ & $3,452,433$ & $17,484,257,728$ & 737,091 & $6,896,987.798$ & $6,357,795$ & 11.2 \\
\hline A.K & 28 & - & 46,200 & $631,687,845$ & 208,976 & $361,472,226$ & 53,688 & $1,221,877,796$ & . & - \\
\hline GB & 27 & . & 18,282 & $563,803,619$ & 58,923 & $1,45,684,062$ & 18,031 & $563.528,617$ & . & . \\
\hline FATA & . & - & - & $\cdot$ & - & - & - & $\cdot$ & - & - \\
\hline ICT & 47 & . & 8,856 & $118,229,593$ & 28,654 & $84,464,732$ & 5,313 & $135,083,000$ & 74,750 & 11.8 \\
\hline $\begin{array}{l}\text { Grand } \\
\text { Iotd }\end{array}$ & $237 \pi$ & 12 & $23,14,199$ & $61,192,561,286$ & $7,323,600$ & $37,820,177,896$ & $3,329,085$ & $45,661,407,546$ & $27,407,048$ & 11.5 \\
\hline
\end{tabular}




\begin{tabular}{|l|r|}
\hline Table 1. Survey Areas \\
\hline Area & no. of respondents \\
\hline Dadu & 32 \\
\hline Mirpurkhas & 26 \\
\hline Matthiari & 22 \\
\hline Tando Allahyar & 24 \\
\hline Moro & 25 \\
\hline Noshero feroz & 24 \\
\hline Total & $\mathbf{1 5 3}$ \\
\hline
\end{tabular}

\begin{tabular}{|l|lr|r|}
\hline \multicolumn{4}{|l|}{ Table 2. Gender wise Distribution } \\
\hline Gender & no. of Respondents & \multicolumn{1}{l|}{} \\
\hline Male & 95 & $62 \%$ \\
\hline Female & 58 & $38 \%$ \\
\hline Total & $\mathbf{1 5 3}$ & $\mathbf{1 0 0 \%}$ \\
\hline
\end{tabular}

\begin{tabular}{|l|r|r|}
\hline Table 3. Category of Micro Finance Availed \\
\hline Category of Loan & no. of Respondents & \multicolumn{1}{l|}{} \\
\hline Agri Based & $\mathbf{6 9}$ & $\mathbf{4 5 \%}$ \\
\hline Crop & 24 & $35 \%$ \\
\hline Dairy/Cattle etc & 45 & $65 \%$ \\
\hline Business Based & $\mathbf{8 4}$ & $\mathbf{5 5 \%}$ \\
\hline New Business & 46 & $68 \%$ \\
\hline Existing Business & 57 & $32 \%$ \\
\hline Total & $\mathbf{1 5 3}$ & $\mathbf{1 0 0 \%}$ \\
\hline
\end{tabular}




\begin{tabular}{|l|r|r|}
\hline Table 4. Micro Finance Amount \\
\hline Micro Finance Availed (Rs.) & No. of Respondents & \multicolumn{1}{l|}{$\%$} \\
\hline $10000-25000$ & 37 & $24 \%$ \\
\hline $25001-50000$ & 60 & $39 \%$ \\
\hline $50001-100000$ & 31 & $20 \%$ \\
\hline $100001-150000$ & 16 & $11 \%$ \\
\hline $150001-300000$ & 8 & $5 \%$ \\
\hline $300001-500000$ & 1 & $1 \%$ \\
\hline Total & 153 & $\mathbf{1 0 0} \%$ \\
\hline
\end{tabular}

\begin{tabular}{|r|rr|}
\hline \multicolumn{2}{|c|}{ Table 5 Reliability Statistics } \\
\hline \multicolumn{2}{|r|}{ Cronbach's Alpha } & N of Items \\
\hline & .678 & \\
\hline
\end{tabular}

Table 6A. Contingency Table

for Income Level UP TO 8000

\begin{tabular}{|l|r|r|r|}
\hline & $\begin{array}{r}\text { Observed } \\
\mathrm{N}\end{array}$ & $\begin{array}{r}\text { Expected } \\
\mathrm{N}\end{array}$ & $\begin{array}{r}\text { Residua } \\
1\end{array}$ \\
\hline before & 51 & 49.5 & 1.5 \\
after & 48 & 49.5 & -1.5 \\
Total & 99 & & \\
\hline
\end{tabular}

Table 6B. Contingency Table for

Income Level UP TO 8001 TO 15000

\begin{tabular}{|l|r|r|r|}
\hline & $\begin{array}{c}\text { Observed } \\
\mathrm{N}\end{array}$ & Expected N & Residual \\
\hline before & 68 & 74.0 & -6.0 \\
after & 80 & 74.0 & 6.0 \\
Total & 148 & & \\
\hline
\end{tabular}


Table 6C. Contingency Table for

Income Level UP TO 8000MORE

THAN 15000

\begin{tabular}{|l|r|r|r|}
\hline & $\begin{array}{r}\text { Observed } \\
\mathrm{N}\end{array}$ & $\begin{array}{r}\text { Expected } \\
\mathrm{N}\end{array}$ & Residual \\
\hline before & 34 & 29.5 & 4.5 \\
after & 25 & 29.5 & -4.5 \\
Total & 59 & & \\
\hline
\end{tabular}

Table 7. Test Statistics

\begin{tabular}{|l|r|r|r|}
\hline & $\begin{array}{c}\text { UP TO } \\
8000\end{array}$ & $\begin{array}{c}8001 \mathrm{TO} \\
15000\end{array}$ & $\begin{array}{c}\text { MORE } \\
\text { THAN } \\
15000\end{array}$ \\
\hline Chi-Square & .091 & .973 & 1.373 \\
df & 1 & 1 & 1 \\
Asymp. & .763 & .324 & .241 \\
Sig. & & & \\
\hline
\end{tabular}

Table 8 Results of Regression

\begin{tabular}{|l|l|l|}
\hline Independent Variables & Coefficient & sig Value \\
\hline Loan Amount Received & 0.0021 & 0.251 \\
\hline Expense & 0.214 & $0.049^{*}$ \\
\hline No of Earning Members & 0.089 & $0.055^{* *}$ \\
\hline No of Family Members & -0.0014 & 0.241 \\
\hline F-Stats & 24.981 & \\
\hline & & \\
Adj R Square & 0.614 \\
\hline
\end{tabular}

*Significant at $5 \%$ level

** Significant at $10 \%$ level 
Table 9: One Sample T Test (Test Value is 4)

\begin{tabular}{|c|c|c|c|c|c|}
\hline \multicolumn{2}{|r|}{ Survey Questions/Hypotheses } & $\begin{array}{l}\text { Number of } \\
\text { Respondent } \\
\mathrm{S}\end{array}$ & Mean & $\begin{array}{l}\text { Mean } \\
\text { Difference }\end{array}$ & Sig Value \\
\hline Q.No & \multicolumn{5}{|c|}{ Do you feel Micro Loan has improved your Economic Conditions } \\
\hline 1 & $\begin{array}{l}\text { Monthly Income has increased } \\
\text { after taking Micro Loan }\end{array}$ & 153 & 2.8656 & -1.64935 & .000 \\
\hline 2 & $\begin{array}{l}\text { Business has improved after } \\
\text { taking Micro Loan }\end{array}$ & 153 & 2.4228 & -1.68182 & .000 \\
\hline 3 & $\begin{array}{l}\text { Business can be expanded by } \\
\text { taking Micro Loan }\end{array}$ & 153 & 3.3084 & -1.79221 & .000 \\
\hline 4 & $\begin{array}{l}\text { Do you feel Micro Loan has } \\
\text { improved your Economic } \\
\text { Conditions }\end{array}$ & 153 & 2.124 & -1.35065 & .000 \\
\hline & \multicolumn{5}{|c|}{ Do you feel Micro Loan has improved your Life Style } \\
\hline 5 & $\begin{array}{l}\text { Clothing of borrower has } \\
\text { improved after taking Micro } \\
\text { Loan }\end{array}$ & 153 & 4.012 & .32468 & .000 \\
\hline 6 & $\begin{array}{l}\text { Footwear of borrower has } \\
\text { improved after taking Micro } \\
\text { Loan }\end{array}$ & 153 & 4.231 & .07143 & .160 \\
\hline 7 & $\begin{array}{l}\text { Travelling Style of borrower } \\
\text { has improved after taking } \\
\text { Micro Loan }\end{array}$ & 153 & 4.432 & .21429 & .004 \\
\hline 8 & $\begin{array}{l}\text { Do you feel Micro Loan has } \\
\text { improved your Life Style }\end{array}$ & 153 & & .06494 & .212 \\
\hline & \multicolumn{5}{|c|}{ Do you feel Micro Loan has made improvement in your Health Needs } \\
\hline 9 & $\begin{array}{l}\text { Borrowers can Easily } \\
\text { Approach to better Medical } \\
\text { Centre after taking Micro } \\
\text { Loan }\end{array}$ & 153 & 4.152 & -1.6948 & .000 \\
\hline 10 & $\begin{array}{l}\text { Borrowers can Easily } \\
\text { Nutrition Need After taking } \\
\text { Micro Loan }\end{array}$ & 153 & 2.7549 & -1.41558 & .000 \\
\hline 11 & $\begin{array}{l}\text { Borrowers can Easily Afford } \\
\text { Medicines After Taking Micro } \\
\text { Loan }\end{array}$ & 153 & 3.1977 & -1.44156 & .000 \\
\hline 12 & $\begin{array}{l}\text { Do you feel Micro Loan has } \\
\text { made improvement in your } \\
\text { Health Needs }\end{array}$ & 153 & & -1.24675 & .000 \\
\hline
\end{tabular}




\begin{tabular}{|c|c|c|c|c|c|}
\hline \multirow[b]{2}{*}{13} & \multicolumn{5}{|c|}{ Do you feel Micro Loan has made improvement in your Education Needs } \\
\hline & $\begin{array}{l}\text { Borrowers can Easily Afford } \\
\text { Better Schooling after taking } \\
\text { Micro Loan }\end{array}$ & 153 & 4.215 & -1.24675 & .000 \\
\hline 14 & $\begin{array}{l}\text { Borrowers can Easily Afford } \\
\text { Schooling Needs of Children } \\
\text { After taking Micro Loan }\end{array}$ & 153 & 2.7549 & -1.55844 & .000 \\
\hline 15 & $\begin{array}{l}\text { Borrowers can Easily Afford } \\
\text { Higher Education After } \\
\text { Taking Micro Loan }\end{array}$ & 153 & 2.69955 & -1.22727 & .000 \\
\hline 16 & $\begin{array}{l}\text { Do you feel Micro Loan has } \\
\text { made improvement in your } \\
\text { Education Needs }\end{array}$ & 153 & & -1.07143 & .000 \\
\hline & \multicolumn{5}{|c|}{ Response of Borrowers about Micro Finance Terms } \\
\hline 17 & $\begin{array}{l}\text { Loan Amount provided is } \\
\text { sufficient for the Borrowers } \\
\text { Need }\end{array}$ & 153 & 2.6442 & -.81169 & .000 \\
\hline 18 & $\begin{array}{l}\text { Repayment Schedule can } \\
\text { easily be satisfied }\end{array}$ & 153 & 2.3121 & .22078 & .001 \\
\hline 19 & $\begin{array}{l}\text { The Rate of Interest charged is } \\
\text { Reasonable }\end{array}$ & 153 & 2.561 & -.29412 & .004 \\
\hline 20 & $\begin{array}{l}\text { Terms of Mocro Finance Loan } \\
\text { are Satisfactory }\end{array}$ & 153 & 3.021 & -.35065 & .004 \\
\hline
\end{tabular}

